\title{
Weed Populations, Sweet Corn Yield, and Economics Following Fall Cover Crops
}

\author{
Kelsey A. O’Reilly, Darren E. Robinson, Richard J. Vyn, and Laura L. Van Eerd*
}

\begin{abstract}
The effectiveness of cover crops as an alternative weed control strategy should be assessed as the demand for food and fiber grown under sustainable agricultural practices increases. This study assessed the effect of fall cover crops on weed populations in the fall and spring prior to sweet corn planting and during sweet corn growth. The experiment was a split-plot design in a pea cover-cover crop-sweet corn rotation with fall cover crop type as the main plot factor and presence or absence of weeds in the sweet corn as the split-plot factor. The cover crop treatments were a control with no cover crop (no-cover), oat, cereal rye (rye), oilseed radish (OSR), and oilseed radish with rye (OSR+rye). In the fall, at Ridgetown, weed biomass in the OSR treatments was 29 and $59 \mathrm{~g} \mathrm{~m}^{-2}$ lower than in the no-cover and the cereal treatments, respectively. In the spring, OSR+rye and rye reduced weed biomass, density, and richness below the levels observed in the control at Bothwell. At Ridgetown in the spring, cover crops had no effect on weed populations. During the sweet corn season, weed populations and sweet corn yields were generally unaffected by the cover crops, provided OSR did not set viable seed. All cover crop treatments were as profitable as or more profitable than the no-cover treatment. At Bothwell profit margins were highest for oat at almost Can $\$ 600 \mathrm{ha}^{-1}$ higher than the no-cover treatment. At Ridgetown, compared with the no-cover treatment, OSR and OSR+rye profit margins were between Can $\$ 1,250$ and $\operatorname{Can} \$ 1,350 \mathrm{ha}^{-1}$ and between Can $\$ 682$ and Can $\$ 835 \mathrm{ha}^{-1}$, respectively. Therefore, provided that OSR does not set viable seed, the cover crops tested are feasible and profitable options to include in sweet corn production and provide weed-suppression benefits.
\end{abstract}

Nomenclature: Cereal rye, Secale cereale L.; oat, Avena sativa L.; oilseed radish, Raphanus sativus L. var. oleoferus Metzg. Stokes; pea, Pisum sativum L.; sweet corn, Zea mays L.

Key words: Catch crops, vegetable production, profit margins, cost-benefit analysis, species richness, Simpson's index.

La efectividad de los cultivos de cobertura como una estrategia alternativa para el control de malezas debe ser evaluada, en vista del incremento en la demanda de alimentos y fibras cultivadas bajo prácticas agrícolas sustentables. Este estudio evaluó el efecto de cultivos de cobertura de otoño en las poblaciones de maleza en la misma estación, en la primavera anterior a la siembra y durante el crecimiento del maíz dulce. El diseño del experimento fue de parcela divida con la rotación de chícharo-cultivo de cobertura-maíz dulce, con el tipo de cultivo de cobertura de otoño como factor principal de la parcela y con la presencia o ausencia de malezas en el maíz dulce como el factor de la parcela dividida. Los tratamientos de cultivos de cobertura fueron: un testigo sin cultivo de cobertura, avena, centeno, rábano oleaginoso, y rábano oleaginoso + centeno. En Ridgetown, durante el otoño, la biomasa de la maleza con los tratamientos de rábano oleaginoso fue 29 y $59 \mathrm{~g} \mathrm{~m}-2$ menor que en el testigo y los tratamientos de avena y centeno, respectivamente. En la primavera, el rábano oleaginoso + centeno y centeno redujeron la biomasa de la maleza, la densidad y la riqueza de la flora por debajo de los niveles observados en la parcela testigo en Bothwell. En Ridgetown, en la primavera, los cultivos de cobertura no tuvieron efecto en las poblaciones de maleza. Durante la estación del maíz dulce, las poblaciones de maleza y el rendimiento del maíz, generalmente, no se vieron afectados por los cultivos de cobertura, siempre y cuando el rábano oleaginoso no produjera semillas viables. Todos los tratamientos de cultivos de cobertura fueron tan o más lucrativos que los tratamientos sin cobertura. En Bothwell, los márgenes de utilidad fueron mayores para la avena, con casi 600 dólares canadienses por ha-1, más que los que no tuvieron cultivo de cobertura. En comparación con el tratamiento sin cobertura, en Ridgetown, los márgenes de utilidad para el rábano oleaginoso y el rábano oleaginoso + centeno fueron entre 1,250 y 1,350 y entre 682 y 835 dólares canadienses por ha-1, respectivamente. Por lo tanto, siempre y cuando el rábano oleaginoso no produzca semillas viables, los cultivos de cobertura probados serían opciones factibles y lucrativas para incluir en la producción de maíz dulce y proporcionar beneficios en la supresión de malezas.

Sweet corn is the most extensive field-grown vegetable crop in Canada with over 30,000 ha of land in production, yielding 250,000 to 300,000 t of corn per year. Ontario has the largest sweet corn production in Canada, with approximately $50 \%$ of

\footnotetext{
DOI: 10.1614/WT-D-10-00051.1

* First and fourth authors: Graduate Student and Associate Professor, School of Environmental Sciences, University of Guelph Ridgetown Campus, Ridgetown, ON NOP 2C0, Canada; Second author: Associate Professor, Department of Plant Agriculture, University of Guelph Ridgetown Campus, Ridgetown, ON NOP 2C0, Canada; Third author: Assistant Professor, Department of Food, Agricultural \& Resource Economics, University of Guelph Ridgetown Campus, Ridgetown, ON NOP 2C0, Canada. Corresponding author's E-mail: lvaneerd@ridgetownc.uoguelph.ca
}

the national acreage and a farm value of Can $\$ 25.5$ million in 2007 (Mailvaganam 2008). North American consumers are more aware of where and how their food is produced, which has lead to increased pressure on growers to produce safe food with minimal environmental impact. Cover crops are currently being incorporated into many production systems due to their ability to reduce soil erosion and runoff; increase soil aeration, water infiltration, and soil organic matter; and improve nutrient cycling (Lu et al. 2000). However, assessing the value of cover crops prior to sweet corn production is necessary not only in terms of economic returns but also the impact of cover crops on subsequent crop inputs, such as fertilizer and pesticides. 
Numerous studies have examined the ability of cover crops to suppress weeds (Brennan and Smith 2005; Burgos and Talbert 1996; Galloway and Weston 1996; Malik et al. 2008; Ngouajio and Mennan 2005; Peachey et al. 2004); however, fewer studies have evaluated weed dynamics in the cropping season following cover crop growth. Moreover, results have varied depending on the cover crop, the subsequent main crop, and the season. Cereals, such as oat, barley (Hordeum vulgare L.), and especially rye, are commonly grown cover crops because of their weed-suppression abilities. For instance, fall-planted cereal cover crops lowered weed biomass in the spring before crop planting (Peachey et al. 2004). In some cases, cereal cover crops can control weeds throughout main crop production, such as rye in subsequent cucumber (Cucumis sativus L.) production (Ngouajio and Mennan 2005). In sweet corn, fall-seeded rye may reduce weeds by 50 to $99 \%$ during early subsequent main crop growth, but the effect may be transient (Burgos and Talbert 1996; Galloway and Weston 1996).

Brassica species, such as oilseed radish (OSR) and wild radish (Raphanus raphanistrum L.), produce glucosinolates that are converted to isothiocyanates, which suppress weeds (Vaughn and Boyston 1997; Boydston and Hang 1995), but weed suppression is often short term (Brennan and Smith 2005) and not effective over the subsequent main crop growing season (Malik et al. 2008). Mixtures of cover crops, such as rye and hairy vetch (Vicia villosa Roth), may also control weeds in sweet corn (Carrera et al. 2004). Mixtures can improve resource capture relative to the monocultures of their respective component crops both spatially and temporally (Fukai and Trenbath 1993). Enhanced resource capture will typically augment the weed-suppressive potential of cover crops (Mohler and Teasdale 1993).

The benefits of winter cover crops in vegetable production also may extend beyond weed management considerations to provide economic benefits. Economic analyses of cover crop systems generally focus on comparing seed costs to the economic benefits from increased yields or from reduced input costs (Sarrantonio and Gallandt 2003). When only nitrogen fertilizer replacement values (Mallory et al. 1998) or reduced chemical inputs (Creamer et al. 1996) were considered, cover crops were often uneconomical. However, in a review of the agronomic and economic literature on the use of cover crops, Lu et al. (2000) indicated that the profitability of cover crop systems is associated with increased main crop yields rather than reduced input costs (Frye et al. 1985; Kelly et al. 1995; Varco et al. 1999; Yiridoe et al. 1993). Legume cover crops, particularly hairy vetch, resulted in higher profits in corn production than nonleguminous cover crops (Hanson et al. 1993; Larson et al. 1998; Lichtenberg et al. 1994; Varco et al. 1999). Accordingly, in literature reviews, a number of studies that consider the effects of increased yields have found that cover crops can increase profitability in some production systems but not in others ( $\mathrm{Lu}$ et al. 2000; Snapp et al. 2005). In contrast, others have found no economic advantage to fall planted cover crops in field corn (Bollero and Bullock 1994; Roberts et al. 1998). In the aforementioned studies, the differences in profitability of cover crops and regional differences in cover crop growth make it difficult to draw conclusions about the economic viability of specific cover crop systems in sweet corn production.

Despite the various potential benefits of cover crops, many growers are hesitant to plant them because of concerns that cover crops may increase weed pressure in the following crop, make seedbed preparation more difficult in the spring, and/or present possible negative effects of cover crops on subsequent crop yield as well as a potential for increased costs without increased returns. There is currently little data available regarding these concerns in vegetable production, especially the effect of cover crops on profit margins and weed pressure in subsequent sweet corn production under normal herbicide regimes. Such information is critical to facilitate decisionmaking regarding the incorporation of cover crops into current production systems. Consequently, the objective of this study was to determine the impacts of various cover crops on economics, weed dynamics, and yield in sweet corn production under typical herbicide programs.

\section{Materials and Methods}

Experimental Design. Research was conducted from 2006 to 2007 in a production field near Bothwell, ON, Canada $\left(42^{\circ} 66^{\prime} \mathrm{N}, 81^{\circ} 95^{\prime} \mathrm{W}\right)$ and from 2007 to 2008 at the University of Guelph Ridgetown Campus, Ridgetown, ON, Canada $\left(42^{\circ} 46^{\prime} \mathrm{N}, 81^{\circ} 89^{\prime} \mathrm{W}\right)$. Soil types were a Brady Loamy Sand and a Brookston Sandy Loam (Typic Hapludalfs) at Bothwell and Ridgetown, respectively. The experiment, which was part of a larger study assessing $\mathrm{N}$ dynamics, was a splitplot arrangement in a randomized complete block design with four replications in a pea-cover crop-sweet corn rotation. The main plot factor was fall cover crop type and the split-plot factor was presence (weedy) or absence (nonweedy) of weeds in the sweet corn crop. The cover crop treatments were a control with no cover crop (no-cover), oat ('Manotick'), cereal rye ('Common \#1'), OSR ('Common \#1') (Ridgetown only), and OSR plus cereal rye (OSR+rye). The nonweedy sections were hand-hoed at planting in Ridgetown or $42 \mathrm{~d}$ after planting at Bothwell until harvest; weedy sections were not hoed. Each main plot was 6 by $8 \mathrm{~m}$, while each weedy splitplot was $2.3 \mathrm{~m}$ (three $76-\mathrm{cm}$ sweet corn rows) wide by $8 \mathrm{~m}$ long, and each nonweedy split-plot was $3.8 \mathrm{~m}$ (five rows) wide by $8 \mathrm{~m}$ long.

After pea harvest, the entire area was disked and cultivated prior to cover crop planting (Table 1). Oat, rye, OSR, and ORS+rye were planted with a drill at rates of $81,67,16$, and $9+34 \mathrm{~kg} \mathrm{ha}^{-1}$, respectively. At Ridgetown, the no-cover plots were sprayed with diquat and glyphosate at 300 and $810 \mathrm{~g}$ ai ha ${ }^{-1}$, respectively, to keep the no-cover treatment weed free to facilitate study of $\mathrm{N}$ dynamics. The following spring at both sites, to kill the rye cover crops, the entire trial was sprayed with glyphosate at $810 \mathrm{~g}$ ai ha ${ }^{-1}$, disked and cultivated before sweet corn ('Temptation') planting at 59,300 plants ha ${ }^{-1}$. Sweet corn plant row and within row spacing was 76.2 and $21.6 \mathrm{~cm}$, respectively. Calcium ammonium nitrate (27-0-0) was broadcast applied by hand at $140 \mathrm{~kg} \mathrm{~N} \mathrm{ha}^{-1}$ and incorporated prior to sweet corn planting. Herbicides were applied to control weeds that had emerged early—primarily 
Table 1. Chronology of field operations and sampling.

\begin{tabular}{|c|c|c|}
\hline Crop/activity & Bothwell & Ridgetown \\
\hline \multicolumn{3}{|l|}{ Cover crop } \\
\hline Planting & August 4, 2006 & July 19, 2007 \\
\hline $\begin{array}{l}\text { Diquat application to } \\
\text { no-cover plots }\end{array}$ & - & September 25, 2007 \\
\hline $\begin{array}{l}\text { Glyphosate application } \\
\text { to no-cover plots }\end{array}$ & - & October 17, 2007 \\
\hline Cover crop sampling & & September $19,2007^{a}$ \\
\hline & October 6, 2006 & $\begin{array}{l}\text { October } 9,2007^{\mathrm{a}} \\
\text { October } 30,2007^{\mathrm{a}}\end{array}$ \\
\hline & December 12, 2006 & $\begin{array}{l}\text { November 23, } 2007^{\text {a }} \\
\text { April 21, } 2008\end{array}$ \\
\hline & May 3, 2007 & May 5, 2008 \\
\hline & May 15, 2007 & May 26, 2008 \\
\hline Spring weed survey & May 3, 2007 & May 5, 2008 \\
\hline $\begin{array}{l}\text { Glyphosate } \\
\text { application (entire trial) }\end{array}$ & May 10, 2007 & May 8, 2008 \\
\hline \multicolumn{3}{|l|}{ Sweet corn crop } \\
\hline$s$-metolachlor application & - & May 29, 2008 \\
\hline Fertilization & May 25, 2007 & June 4, 2008 \\
\hline Planting & May 28, 2007 & $\begin{array}{l}\text { June 4, } 2008 \\
\text { June 7, } 2008\end{array}$ \\
\hline Nicosulfuron application & June 19, 2007 & June 13, 2008 \\
\hline Sodium bentazon application & June 26, 2007 & - \\
\hline Summer weed survey & July 23, 2007 & July 11,2008 \\
\hline & August 16, 2007 & August 7, 2008 \\
\hline Weedy sweet corn harvest & August 13, 2007 & August 5, 2008 \\
\hline Nonweedy sweet corn harvest & August 16, 2007 & August 5, 2008 \\
\hline
\end{tabular}

${ }^{a}$ Weed sampling included.

grasses at Ridgetown and grasses and common lambsquarters (Chenopodium album L.) at Bothwell. The entire trial was sprayed with nicosulfuron at $25 \mathrm{~g}$ ai ha ${ }^{-1}$ with nonionic surfactant Agral 90 at $445 \mathrm{ml} \mathrm{ha}{ }^{1}$ and sodium bentazon at $816 \mathrm{~g} \mathrm{ai} \mathrm{ha}^{-1}$ at Bothwell and $s$-metolachlor (+ safener) at $1,556 \mathrm{~g}$ ai ha ${ }^{-1}$ and nicosulfuron at $25 \mathrm{~g}$ ai ha ${ }^{-1}$ with Agral 90 at $445 \mathrm{ml}$ ai ha ${ }^{-1}$ at Ridgetown (Table 1). Typical Ontario production practices for sweet corn were followed for fertilization and other field management.

Data Collection. At Bothwell, aboveground biomass of cover crops was collected three times in the fall using one $0.5-\mathrm{m}^{2}$ quadrat per plot and twice in the spring using two $0.5-\mathrm{m}^{2}$ quadrats per plot. A spring weed survey, including species count and total weed weight, was completed using two $1-\mathrm{m}^{2}$ quadrats per plot. At Ridgetown, aboveground biomass of cover crops and weeds was collected four times in the fall using one $0.5-\mathrm{m}^{2}$ quadrat per plot. The following spring, cover crop biomass was collected three times using two $0.5-\mathrm{m}^{2}$ quadrats per plot. A spring weed survey, including count and weight by species, was completed using four $0.25-\mathrm{m}^{2}$ quadrats per plot. Quadrat size was based on weed density and the crop present. At both locations in the sweet corn crop, weed surveys were conducted in the weedy split-plots using two $0.25-\mathrm{m}^{2}$ quadrats per split-plot at 28 and $56 \mathrm{~d}$ after herbicide application (DAT).

For each split-plot, species richness, $S$, was calculated as the total number of species per quadrat, pooled for each sample date, and expressed as plant per square meter. At both sites, monocots were grouped as a species for the spring weed surveys only, because grasses were too small for proper identification. Species evenness, $E$, was calculated based on Simpson's dominance index (Simpson 1949):

$$
E=\left(1 / \sum_{i=1}^{S} p_{i}^{2}\right) / S
$$

where $p_{i}$ is the proportional biomass of species $i$. Species evenness was calculated at the Ridgetown site only for the spring sampling date, because weight by species was not recorded at the Bothwell site.

At sweet corn harvest, $6 \mathrm{~m}$ of the center row(s) of each weedy and nonweedy split-plot were hand-harvested. At Ridgetown, weedy and nonweedy plots were harvested on the same day; at Bothwell, the weedy plots were harvested $3 \mathrm{~d}$ after the nonweedy plots due to constraints during hand-harvesting. Harvested ears were separated into marketable and nonmarketable categories based on a stringent examination of each ear. This examination involved opening the husk of each ear and examining ear size, kernel development, and insect damage. If any insect damage or poor kernel development was found, the ear was considered nonmarketable. This was completed due to additional insect research conducted at the sites. Weight and the number of marketable and nonmarketable ears were recorded. A subsample of all plant tissue, including sweet corn yield, was weighed fresh, dried at $60 \mathrm{C}$ and weighed dry. Air temperature and precipitation data were reported for the Ridgetown site only because data from Bothwell were incomplete and thus unreliable; however, annual precipitation and temperature trends at Ridgetown were similar to Bothwell.

Statistical Analyses. Data were analyzed using the GLM procedure of SAS Version $9.1^{1}$ after testing for normality and homogeneity of variance. Data were subjected to ANOVA and means were separated using the Tukey-Kramer adjustment test at the 0.05 probability level. A split-plot analysis was used, in which the split-plot factor was date for the cover crop biomass datasets and fall and summer weed datasets and presence of weeds for sweet corn yield datasets. Split-plot analysis was not required for the spring weed data because samples were taken on only one date and weedy plots had not yet been split. Nonorthogonal contrasts were used to compare weed population data with and without cover crops, and OSR treatments were compared to cereal treatments. Outliers were determined using the boxplot method. When outliers were present, they were removed from the analysis only if the results were significantly affected by their removal. All data from each site were analyzed separately due to the differences in treatments, sampling dates, and physical and environmental factors between the two sites.

Economic Analyses. The economic analyses for this study calculated profit margins over cover crop costs and examined for differences in margins among treatments. These profit margins, which only take into account costs that vary among treatments, were calculated as total revenues less costs associated with cover crops. The assumption was made that all other costs (e.g., sweet corn seed, fertilizers and pesticides applied to sweet corn) were equal across treatments. Total revenues were determined based on the yield for each plot and the average price of sweet corn, as reported by Ontario Ministry of 
Agriculture, Food and Rural Affairs (OMAFRA). ${ }^{2}$ The costs associated with cover crops include seed costs, hiring a custom applicator to plant the cover crops, and herbicide product and custom application in the spring for treatments that included rye. Seed costs for each type of cover crop were provided by seed retailers in southern Ontario. The cost of glyphosate used for the rye burndown was based on prices reported by AGRIS Cooperative Ltd. ${ }^{3}$ The cost of hiring a custom applicator to plant the cover crop and apply the herbicide was determined through OMAFRA's 2006 custom rate survey. ${ }^{4}$

Fisher's LSD was used to determine statistically significant differences in profit margins between treatments, while regression analysis was used to determine whether the use of each cover crop had a significant impact on profit margins relative to no cover crop. The regression equation was

$$
\begin{aligned}
\mathrm{PM}= & \mathrm{a}+\mathrm{b} \times \text { Oats }+\mathrm{c} \times \text { Rye }+\mathrm{d} \times \text { OSR }+\mathrm{e} \\
& \times(\text { OSR }+ \text { rye })
\end{aligned}
$$

where PM is the profit margin over cover crop and fertilizer costs; Oats, Rye, OSR, and OSR+rye are categorical variables representing the use of each cover crop; and a, b, c, d, and e were parameters to be estimated. With all independent variables being categorical, this implies that the regression equation must be linear in nature. This regression equation was analyzed separately for weedy and nonweedy treatments.

\section{Results and Discussion}

Cover Crop Biomass Production. Fall. At Bothwell, cover crop biomass production was affected by cover crop species at both sample dates (Figure 1A). In October, the OSR+rye treatment had higher biomass than the cereals. However, by December, oat and OSR+rye had produced significantly more biomass than rye, which is consistent with the typical slow shoot growth of rye in the fall.

At Ridgetown, cover crop biomass production was also affected by cover crop species at all sample dates (Figure 1B). The OSR+rye and OSR treatments consistently produced more biomass than either oat or rye. At Ridgetown, percent dry matter increased over the season, likely due to ripening seed, which led to high OSR dry biomass. Brennen and Smith (2005) observed similarly, high cover crop biomass production in oats or a mustard mix of Brassica hirta Moench and $B$. juncea (L.) Czern. of 13,000 and 11,000 kg ha ${ }^{-1}$, respectively, in one year and half that amount in another year. At Ridgetown, ripening OSR seed pods, which ultimately produced viable seed, contributed significantly to total aboveground biomass rates. This was not observed at Bothwell. The high biomass production of the OSR and OSR+rye treatments at Ridgetown may have been due to high soil $\mathrm{N}$ levels. At the time of cover crop planting, total mineral soil $\mathrm{N}$ in the 0 - to $30-\mathrm{cm}$ depth was 22 and $106 \mathrm{~kg} \mathrm{~N} \mathrm{ha}^{-1}$ at Bothwell and Ridgetown, respectively. With $\mathrm{N}$ fertilizer, OSR produced nearly twice as much biomass as unfertilized plants under the same conditions (Schomberg et al. 2006).

Biomass production was generally greater at Ridgetown than at Bothwell. This result may be because cover crops were
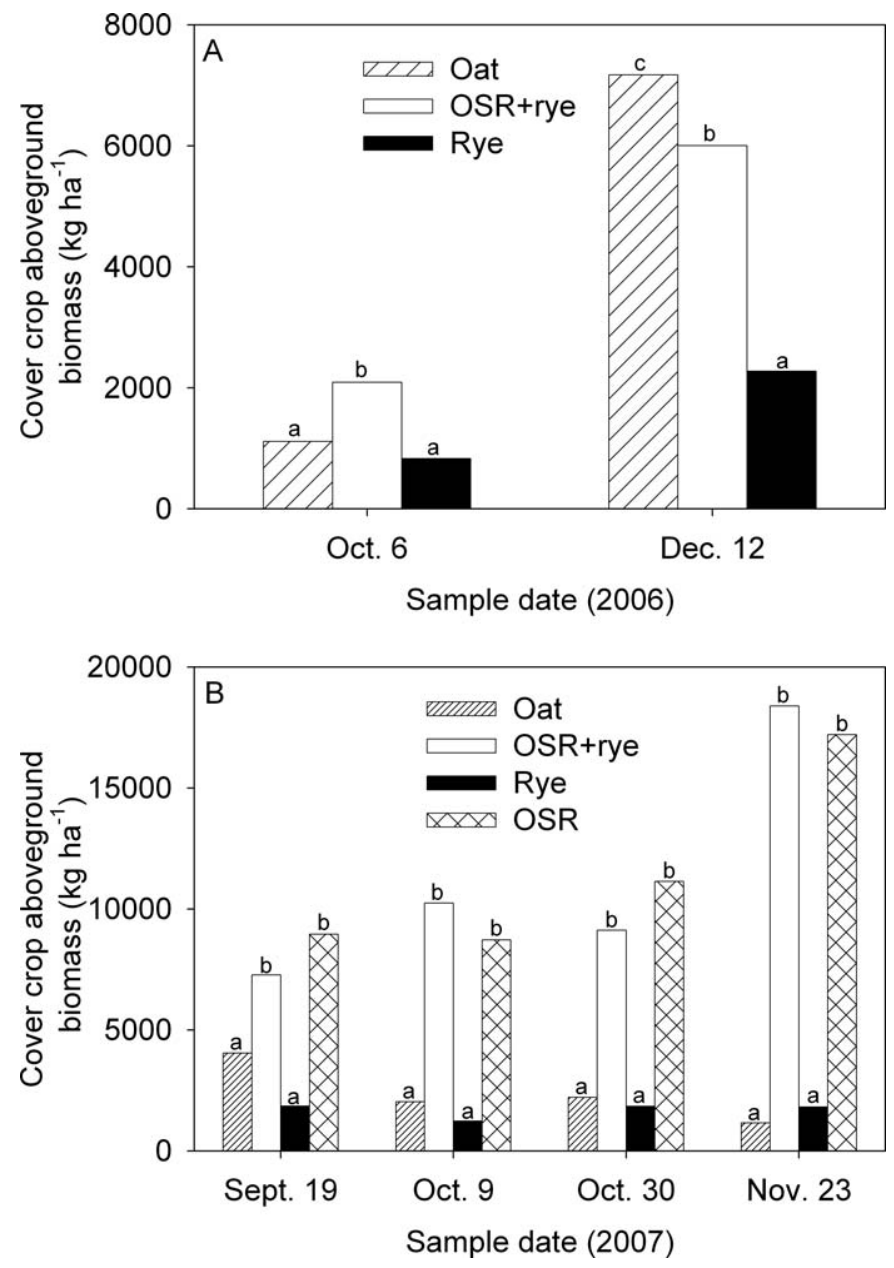

Figure 1. Fall cover crop aboveground biomass dry weight at (A) Bothwell and (B) Ridgetown. At each date, bars with different letters are significantly different based on Tukey-Kramer means separation (0.05). OSR, oilseed radish; OSR+rye, oilseed radish plus rye.

planted 2 wk earlier at Ridgetown and accumulated 550 more growing degree days (GDD, base 4.4 C [Charles et al. 2006]) than at Bothwell between cover crop planting and the last fall sampling date (Figure 2). The higher GDD, combined with early fall rainfall at Ridgetown (Table 2), led to good establishment and quick growth of the cover crops and weeds (Figures 1 and 3); whereas, at Bothwell, growth was delayed in the early season due to less rain and fewer GDD. It is not uncommon for cover crops to produce varying quantities of biomass between years due to differences in weather, cover crop planting date, and cover crop kill date (Barberi and Mazzoncini 2001; Brennan and Smith 2005; Clark et al. 1995).

Spring. At Bothwell, cover crop biomass or residue on the soil surface was affected by cover crop species at both sample dates in the following spring (Figure 4A). In early May, oats had higher biomass than both the OSR+rye and rye treatments. However, by late May, rye growth more than doubled in the rye treatment but not in the OSR+rye treatment. The reduced rye growth in the OSR+rye treatment may be due to less rye biomass in the previous fall due to OSR competition. 


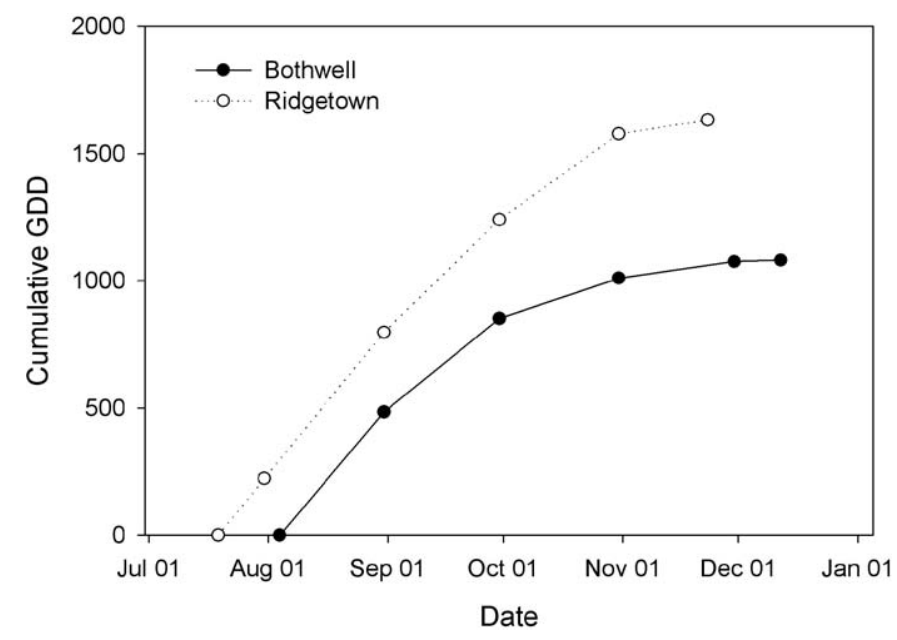

Figure 2. Cumulative growing degree days (GDD base $4.4 \mathrm{C}$ ) during the fall cover crop growing season, beginning at cover crop planting and ending at the last cover crop sample date for each site.

Alternatively, the lower rye biomass in the OSR+rye treatment compared with the rye-only treatment may be a result of the allelopathic effects of OSR (Fahey et al. 2001). Extracts from aboveground tissues of Brassica species reduced germination and growth rates of monocots such as barley and oat (Tawaha and Turk 2003; Turk and Tawaha 2003).

At Ridgetown, cover crop biomass production was affected by cover crop species at all spring sample dates (Figure 4B). With the exception of rye and OSR in late May, OSR+rye and OSR cover crops had higher biomass than the oat and rye treatments due to larger quantities of fall biomass that remained on the soil surface in the spring. This was contrary to Bothwell, where rye had higher biomass than the OSR+rye treatment. By late May at Ridgetown, rye biomass increased due to regrowth, and similar to Bothwell, rye regrowth was less in the OSR+rye treatment than in the rye-only treatment.

Effect of Cover Crops on Weed Populations. Fall. Weed biomass was not collected in the fall at Bothwell because this site was located within a commercial production field and

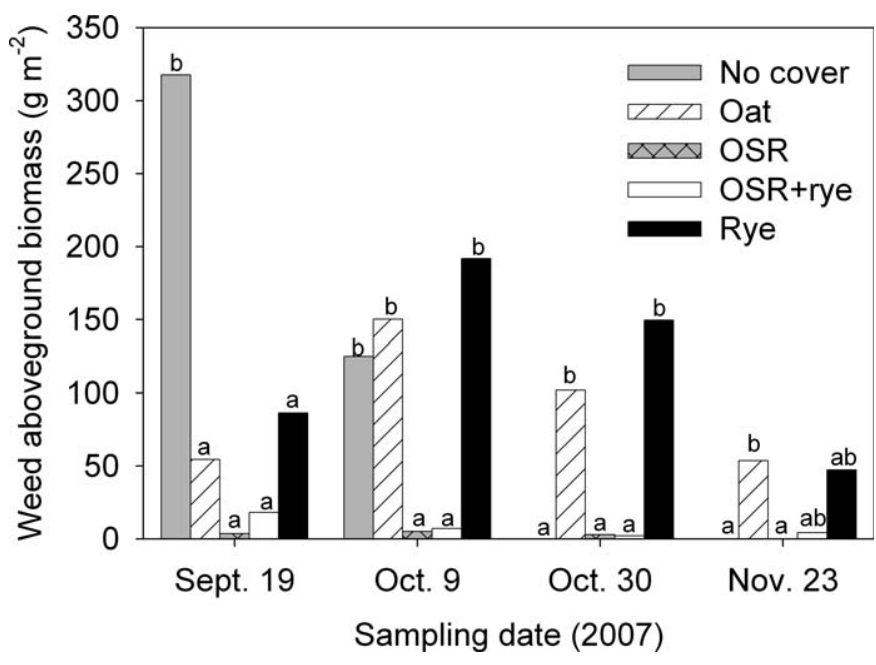

Figure 3. Fall weed aboveground biomass dry weight at Ridgetown. For each date, bars with different letters are significantly different based on Tukey-Kramer means separation (0.05). OSR, oilseed radish; OSR+rye, oilseed radish plus rye.

weed pressure was very low. The Ridgetown site was previously used for weed research trials and had a very large weed seedbank. Weed biomass declined with time for the nocover treatment at Ridgetown (Figure 3) because these plots were sprayed with diquat on September 25, 2007, and glyphosate on October 17, 2007. At the first two sample dates, which occurred before the second herbicide application, none of the cover crop treatments resulted in more weed biomass than the control $(\mathrm{P}<0.001)$. Thus, cover crops reduced fall weed populations.

Prior to the second herbicide application, the OSR and OSR+rye treatments had $131 \mathrm{~g} \mathrm{~m}^{-2}$ less weed biomass than the no-cover control based on contrast analysis (Figure 3). Separate applications of diquat and glyphosate were required to reduce weed populations in the no-cover treatment to levels found in the OSR treatments. Therefore, the use of an OSR cover crop during the fall may prove effective at reducing fall weed populations and consequently may be useful in pesticide-reduction programs.

Table 2. Monthly mean temperature and total precipitation at the University of Guelph Ridgetown Campus, Ridgetown, ON, Canada, in 2006 to 2008 as compared to the 30 -yr mean.

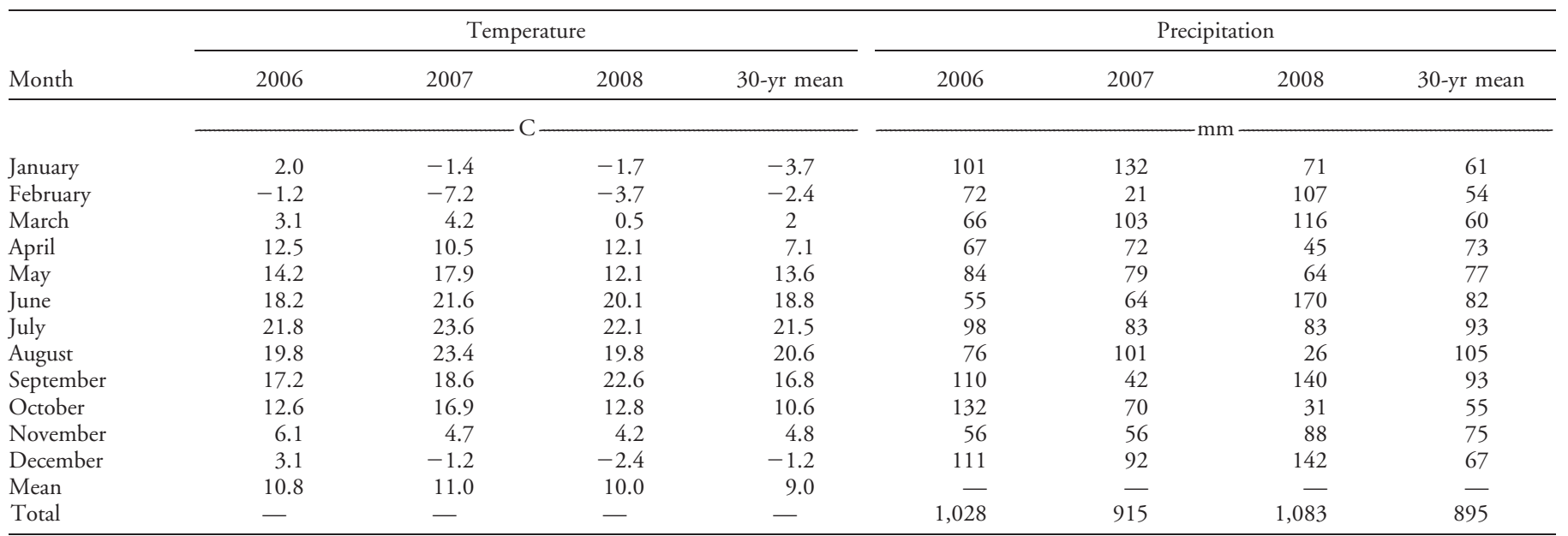



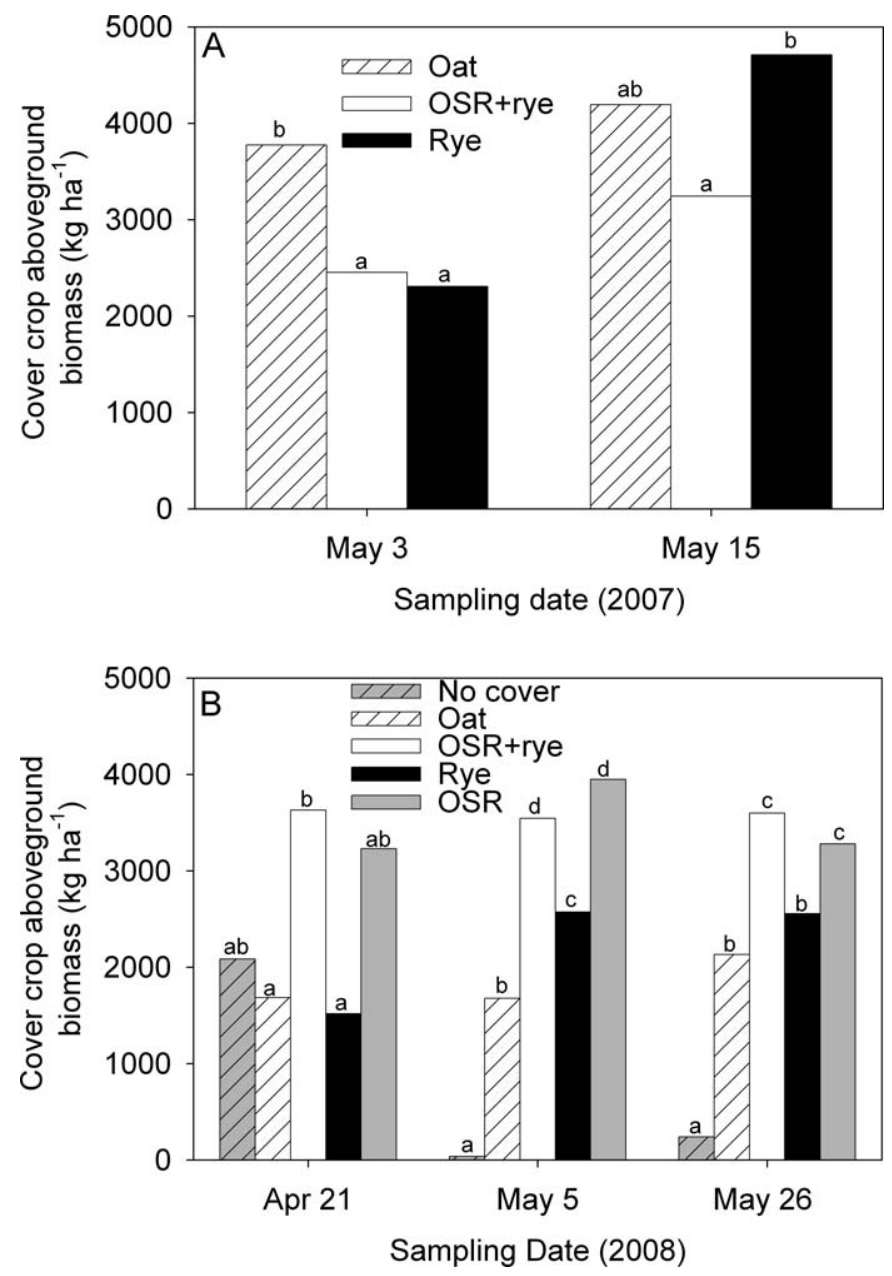

Figure 4. Spring cover crop and weed aboveground biomass dry weight at (A) Bothwell and (B) Ridgetown. For each date, bars with different letters are significantly different based on Tukey-Kramer means separation (0.05). OSR, oilseed radish; OSR+rye, oilseed radish plus rye.

The OSR treatments had $59 \mathrm{~g} \mathrm{~m}^{-2}$ less weed biomass than the cereal cover crops. Similar results have been found for other Brassica cover crop species (Brennan and Smith 2005). The effectiveness of OSR and OSR+rye at reducing weeds, in comparison with the other cover crop treatments, may be due to the allelopathic effects of glucosinolates and isothiocyanates produced by OSR and/or through the prevention of weed seed germination and establishment due to quick biomass production and canopy development (Brennan and Smith 2005; Malik et al. 2008). This was observed at both sites, where the OSR treatments had produced more biomass than the cereals (Figure 1).With its rapid establishment, it is likely that OSR quickly outcompeted weed species for resources, such as sunlight. Therefore, cover crop treatments including an OSR component may be an effective strategy to reduce fall weeds.

It is possible with long-term use of OSR that this cover crop could reduce weed populations in the following year. In a long-term study, rye reduced weed seedbank density, which included weeds with differing germination seasonality, indicating that cover crops may not only affect the weed seedbank species related to the cover crop growing season, but also those related to subsequent corn growing season (Moonen and Barberi 2004). The objectives of this study were to examine the effects of cover crops on weed populations after one crop rotation. Benefits of cover crops are not always found in short-term experiments (Snapp et al. 2005). Thus, long-term studies are needed to assess the effectiveness of OSR at reducing weed populations during sweet corn growth.

Spring. Dicotyledonous weeds accounted for $99 \%$ of the total spring weed population density at both Bothwell and Ridgetown (data not shown). The dominant species at Bothwell were common chickweed [Stellaria media (L.) Vill.], horseweed [Conyza canadensis (L.) Cronq.], and henbit (Lamium amplexicaule L.). The dominant species at Ridgetown were common ragweed (Ambrosia artemisiifolia L.), OSR, and woodsorrel (Oxalis sp.). At Ridgetown, OSR set viable seed in the fall, due to the earlier planting date, the lack of an early killing frost and high GDD compared to Bothwell. This led to a greater number of volunteer OSR plants in the spring in the OSR and OSR+rye treatments. Oilseed radish volunteers were hand-weeded on June 7, 2008, prior to sweet corn emergence, so as not to impede sweet corn growth. At the time of hoeing, OSR volunteer plants ranged from 82 to 684 plants $\mathrm{m}^{-2}$. Justes et al. (1999) observed significantly higher volunteer OSR densities at approximately 2,600 plants $\mathrm{m}^{-2}$. Researchers and growers have identified that OSR and other Brassica cover crops can be a potential weed problem in the following year (Justes et al. 1999; Snapp et al. 2005). Although not part of this study, in the following spring wheat growing season, volunteer OSR were not observed in plots at Ridgetown. Moreover, in $6 \mathrm{yr}$ of conducting research trials at Ridgetown with OSR cover crops, this was the only time volunteer OSR were an issue the following year, likely due to planting in mid-July vs. early August. It is, therefore, unlikely that the adoption of OSR cover crops would lead to a widespread dependence on herbicides or lead to herbicide resistance. Nevertheless, OSR has the potential to become a weed in the following growing season. It is imperative that growers ensure that viable seed is not set in the fall by delaying planting until mid-August or by mowing or controlling it. Alternatively, if OSR sets viable seed, growers should be prepared to adjust weed management practices in the subsequent spring.

At Bothwell, all of the covers reduced total weed biomass compared with the no-cover, but only rye and OSR+rye had lower weed density than the no-cover treatment (Table 3). In addition, the cover crops as a group had lower weed biomass and density than the no-cover treatment $(\mathrm{P}=0.001$ and $\mathrm{P}=0.001$, respectively). Peachey et al. (2004) also found that cover crops of rye, barley, and oats reduced weed biomass in the spring compared with the no-cover control. Weed suppression by cover crops in the spring generally tends to be related to cover crop biomass production in the fall (Ngouajio and Mennan 2005). Decomposing cover crop residue on the soil surface in the spring may provide phytotoxic and/or physical obstruction to weed growth. Effects of plant residues include a decrease in soil temperature, a reduction in diurnal 
Table 3. Weed population parameters in the spring following different cover crops. ${ }^{\text {a }}$

\begin{tabular}{|c|c|c|c|c|c|c|c|c|}
\hline \multirow[b]{2}{*}{ Cover crop } & \multicolumn{2}{|c|}{ Biomass } & \multicolumn{2}{|c|}{ Density } & \multicolumn{2}{|c|}{ Richness $(S)^{\mathrm{b}}$} & \multicolumn{2}{|c|}{ Evenness $(E)^{\mathrm{b}}$} \\
\hline & Bothwell & Ridgetown & Bothwell & Ridgetown & Bothwell & Ridgetown & Bothwell & Ridgetown \\
\hline & 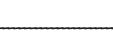 & 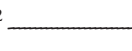 & $\mathrm{pl}$ & -2 & & & & \\
\hline No cover & $23.3 \mathrm{~b}$ & 2.3 & $10.4 \mathrm{~b}$ & $87.3 \mathrm{ab}$ & $2.4 \mathrm{c}$ & 5.3 & - & $0.5 \mathrm{ab}$ \\
\hline Oat & $0.8 \mathrm{a}$ & 7.4 & $1.9 \mathrm{ab}$ & $70.0 \mathrm{ab}$ & $1.0 \mathrm{bc}$ & 4.7 & - & $0.4 \mathrm{ab}$ \\
\hline $\mathrm{OSR}^{\mathrm{c}}$ & - & 2.0 & - & $80.9 \mathrm{ab}$ & - & 5.0 & - & $0.3 \mathrm{a}$ \\
\hline OSR+rye & $0.3 \mathrm{a}$ & 2.3 & $0.4 \mathrm{a}$ & $155.8 \mathrm{~b}$ & $0.1 \mathrm{a}$ & 5.7 & - & $0.4 \mathrm{a}$ \\
\hline Rye & $0.6 \mathrm{a}$ & 1.0 & $0.5 \mathrm{a}$ & $64.8 \mathrm{a}$ & $0.3 \mathrm{ab}$ & 4.7 & - & $0.6 \mathrm{~b}$ \\
\hline
\end{tabular}

${ }^{a}$ Dicotyledonous weeds accounted for $99 \%$ of total weed density at both sites. Dominant species at Bothwell were common chickweed, horseweed, and henbit and at

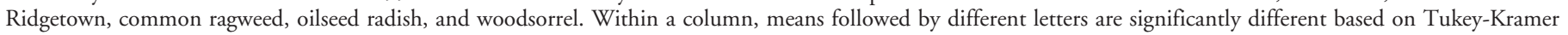

means separation $(0.05)$.
${ }^{\mathrm{b}} S$ calculated as the total number of species per plot; $E$ calculated based on Simpson's dominance index $\left[E=\left(1 / \sum_{i=1}^{s} p_{i}^{2}\right) / S\right]$.

${ }^{c}$ Abbreviations: OSR, oilseed radish; OSR+rye, oilseed radish plus rye; —, indicates that either no sample was taken (OSR treatment not present at Bothwell) or that $E$ was not calculated because it was not possible to take weights by species at Bothwell.

temperature fluctuations, and physical obstruction of weed seed germination (Teasdale 1996).

At Bothwell, the no-cover treatment had a mean $S$ of 2.4, which was higher than that of OSR+rye and rye (Table 3 ). The cover crops as a group had lower $S$ compared to the no-cover treatment, and the OSR treatments had lower $S$ than the cereals $(P=0.001$ and $P=0.032$, respectively). These differences in $S$ may be attributed to the strong reduction in weed biomass and density by the cover crops in comparison with the control, where the OSR+rye and rye treatments reduced weed density to below 1 plant $\mathrm{m}^{-2}$. Species evenness was not calculated for the Bothwell site because weight by species was not determined.

At Ridgetown in the spring, cover crops had no effect on weed biomass (Table 3). Although cover crops did not reduce weed density compared with the no-cover control, rye had lower weed density than OSR+rye. Also, the OSR treatments as a group had higher weed density than the cereals $(\mathrm{P}=0.019)$, which was due to the high number of OSR volunteers. Ngouajio and Mennan (2005) also found no effect of cover crops on weed density $13 \mathrm{~d}$ before cover crop desiccation prior to cucumber production. The lack of effect of cover crops on weed biomass in the spring at Ridgetown may have been due to high weed pressure. The Ridgetown site was previously used for weed management trials and therefore had a higher weed seedbank than typical production fields. Ridgetown had higher weed density and $S$ than the Bothwell site (Table 3). In addition, the no-cover plots had considerable weed biomass in the fall, which likely left enough residue on the surface to mimic the weed-suppressive effects of the cover crops residues.

Species richness ranged from 4.7 to 5.7 at Ridgetown (Table 3), but there were no differences among the treatments, which is consistent with the contrast analyses $(\mathrm{P} \geq 0.432)$. Rye had higher $E$ than both the OSR and OSR+rye treatments; however, none of the cover crops were different from the no-cover control. The relatively low $E$ values indicate that a few species were dominant at Ridgetown even though five species, on average, were present. In the nocover and cereal plots, common ragweed and woodsorrel species were dominant, while in the OSR, treatments, OSR was also a dominant weed. Consistent with contrasts for other parameters at Ridgetown, there was no difference among the covers as a group or the OSR treatments as a group compared with the no-cover control. However, the OSR treatments did have lower $E$ compared to the cereals, due primarily to rye, not oats.

Inconsistencies in cover crop weed suppression between years in the spring have also been reported by others (Barberi and Mazzoncini 2001; Ngouajio and Mennan 2005); however, Peachey et al. (2004) found results similar to those at Bothwell in two consecutive years. Overall, the differences between the two sites can be largely attributed to the larger weed seedbank and weed pressure at Ridgetown than at Bothwell. Also, the high OSR volunteer density in the spring at Ridgetown elevated weed density levels in the OSR and OSR+rye treatments compared with Bothwell, where no OSR volunteers were present. Therefore, under low weed pressure that is typical of most commercial fields, cover crops may be effective at reducing spring weed populations.

Sweet Corn Growing Season. At Bothwell, monocots accounted for $94 \%$ of the total summer weed population. The dominant species was long-spined sandbur [Cenchrus longispinus (Hack.) Fern.], which accounted for $88 \%$ of weeds by dry weight. At Ridgetown, dicots accounted for $81 \%$ of the weed population. The dominant species was common ragweed, which accounted for $63 \%$ of weeds by dry weight. Dates were pooled for each analysis, except for weed biomass at Bothwell, where there was a cover crop by sampling date interaction.

At Bothwell, none of the individual cover crops reduced weed biomass below the no-cover control at either sampling date (Table 4); however, when the cover crops were grouped together, weed biomass was lower than the control $(\mathrm{P}=0.004)$. As well, the OSR+rye treatment did not reduce weed biomass compared with the no-cover or the cereal treatments during the sweet corn growing season $(\mathrm{P}=0.100$ and $\mathrm{P}=0.058$, respectively). There was no difference in density, $S$ or $E$ among the treatments, individually or grouped, with the exception that the cover crops as a group had higher weed density than the no cover due mainly to the higher weed density in rye (Table 4; $\mathrm{P}=0.032$ ). 
Table 4. Weed population parameters during sweet corn growing season following different cover crops. ${ }^{\text {a }}$

\begin{tabular}{|c|c|c|c|c|c|c|c|c|c|}
\hline \multirow[b]{3}{*}{ Cover crop } & \multicolumn{3}{|c|}{ Biomass } & \multicolumn{2}{|c|}{ Density } & \multicolumn{2}{|c|}{ Richness $(S)^{\text {b }}$} & \multicolumn{2}{|c|}{ Evenness $(E)^{\mathrm{b}}$} \\
\hline & \multicolumn{2}{|c|}{ Bothwell } & Ridgetown & Bothwell & Ridgetown & Bothwell & Ridgetown & Bothwell & Ridgetown \\
\hline & $28 \mathrm{DAT}^{\mathrm{c}}$ & 56 DAT & $\begin{array}{c}\text { Combined } \\
\text { dates }\end{array}$ & \multicolumn{2}{|c|}{ Combined dates } & \multicolumn{2}{|c|}{ Combined dates } & \multicolumn{2}{|c|}{ Combined dates } \\
\hline & \multicolumn{3}{|c|}{$-g m^{-2}$} & \multicolumn{2}{|c|}{ - plants $\mathrm{m}^{-2}$} & \multicolumn{2}{|c|}{ \# of species } & \multicolumn{2}{|c|}{ Simpson's index } \\
\hline No cover & $63 \mathrm{ab}$ & $60 \mathrm{ab}$ & $66 \mathrm{ab}$ & 12 & 34 & 1.6 & $2.3 \mathrm{a}$ & 0.9 & $0.5 \mathrm{~b}$ \\
\hline Oat & $64 a b$ & $243 \mathrm{~b}$ & $77 \mathrm{~b}$ & 12 & 38 & 1.3 & $3.6 \mathrm{~b}$ & 0.8 & $0.3 \mathrm{a}$ \\
\hline OSR & - & - & $55 \mathrm{ab}$ & - & 21 & - & $3.2 \mathrm{ab}$ & - & $0.4 \mathrm{ab}$ \\
\hline OSR+rye & $37 \mathrm{a}$ & $195 \mathrm{~b}$ & $44 \mathrm{a}$ & 21 & 28 & 1.3 & $3.4 \mathrm{~b}$ & 0.9 & $0.4 \mathrm{ab}$ \\
\hline Rye & $61 \mathrm{ab}$ & $223 \mathrm{~b}$ & $78 \mathrm{~b}$ & 33 & 46 & 1.6 & $4.0 \mathrm{~b}$ & 0.8 & $0.3 \mathrm{a}$ \\
\hline
\end{tabular}

${ }^{a}$ Dominant species were long-spined sandbur ( $88 \%$ of weeds by dry weight) and common ragweed (63\%) at Bothwell and Ridgetown, respectively. Within a column,

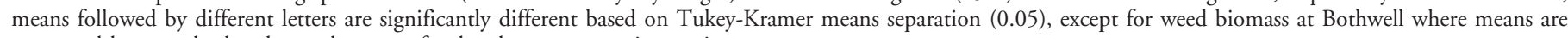

compared between both columns because of a date by cover crop interaction.
${ }^{b} S$ calculated as the total number of species per plot; $E$ calculated based on Simpson's dominance index $\left[E=\left(1 / \sum_{i=1}^{s} p_{i}^{2}\right) / S\right]$.

'Abbreviations: DAT, days after herbicide treatment; OSR, oilseed radish; OSR+rye, oilseed radish plus rye.

At Ridgetown, none of the cover crops, individually or grouped, had weed biomass different from the no cover (Table 4). But, both oat and rye had higher weed biomass than the OSR+rye treatment and the grouped OSR treatments had lower weed biomass compared to the cereals (Table 4; $\mathrm{P}=0.003$ ). Individually, none of the cover crops affected total weed density compared to one another (Table 4). However, the OSR treatments combined were more effective at reducing density than the cereal cover crops combined $(\mathrm{P}=0.009)$. The no-cover control had an $S$ of 2.3, which was no different than OSR, but lower than the other treatments. As well, the no-cover treatment had a lower $S$ than all cover treatments grouped and the OSR treatments. Species evenness ranged from 0.3 to 0.5 , and oat and rye had a lower $E$ than the no cover. In addition, the cover crops as a group had a lower $E$ than the no cover, while weed populations were more evenly distributed in the OSR treatments than the cereals.

Similar to this study, others have observed inconsistencies in $S$ reduction among cover crop treatments between years (Ngouajio et al. 2003; Ngouajio and Mennan 2005). The differences between sites in this study may be attributed to differences in the number and type of species present. At Bothwell, the weed population consisted almost entirely of one species (long-spined sandbur), while at Ridgetown, more species were present, but one species (common ragweed) dominated the population. In some cases, high $S$ reduced the density of competitive species in a weed population (Moonen and Barberi 2004); however, the high density of the one competitive species at Ridgetown as indicated by low $E$ values, reduced the effects of the changes in $S$. Therefore, the differences in $S$ between the treatments at Ridgetown may be inconsequential.

Although there were some differences in weed biomass among cover crop species, the cover crop treatments did not greatly affect weed biomass or density compared with the nocover treatment at either site during the sweet corn growing season (Table 4). Similar results have been found in sweet corn at $4 \mathrm{wk}$ (Malik et al. 2008; Peachey et al. 2004) and $8 \mathrm{wk}$ after planting (Galloway and Weston 1996) and in field corn
(Barberi and Mazzoncini 2001; Johnson et al. 1993). In soybean [Glycine max (L.) Merr.], rye was also ineffective at lowering weed density and biomass below the no-cover treatment (Koger et al. 2002). Nonetheless, cover crops have lowered weed biomass compared to the no-cover control in cucumber (Ngouajio and Mennan 2005) and lettuce (Lactuca sativa L.) (Ngouajio et al. 2003); however, these studies involved the use of summer cover crops, and therefore, weed populations may have been affected differently than with winter cover crops.

Cover crops typically have not provided adequate weed suppression through the entire corn growing season (Barberi and Mazzoncini 2001; Teasdale 1996). The effectiveness of the OSR treatments to suppress weeds compared to the cereals was inconsistent between Bothwell and Ridgetown sites, and although the OSR treatments were more effective than the cereals at Ridgetown, they still did not lower weed populations relative to those in the no-cover treatment in the sweet corn growing season. The general lack of difference in performance of the OSR and cereal treatments was consistent with Malik et al. (2008) who observed no

Table 5. Total and marketable sweet corn yield as affected by cover crop and weed treatments. ${ }^{a}$

\begin{tabular}{lccccc}
\hline & \multicolumn{2}{c}{ Total yield } & & \multicolumn{2}{c}{ Marketable yield } \\
\cline { 2 - 3 } \cline { 5 - 6 } & Bothwell & Ridgetown & & Bothwell & Ridgetown \\
\cline { 2 - 3 } & & & & & \\
\cline { 5 - 6 } Cover crop treatment & & & & \\
No cover & $12.0 \mathrm{a}$ & 24.4 & & 8.5 & 5.2 \\
Oat & $15.5 \mathrm{~b}$ & 23.2 & & 12.4 & 6.7 \\
OSR & - & 30.1 & & - & 7.5 \\
OSR+rye & $13.0 \mathrm{a}$ & 29.0 & & 9.4 & 7.9 \\
Rye & $13.1 \mathrm{ab}$ & 29.2 & & 9.0 & 14.7 \\
Weed treatment & & & & \\
Weedy & 13.2 & $15.9 \mathrm{a}$ & 10.3 & $3.0 \mathrm{a}$ \\
Nonweedy & 13.8 & $45.9 \mathrm{~b}$ & 9.1 & $19.6 \mathrm{~b}$ \\
\hline
\end{tabular}

${ }^{a}$ Within a column, for a given treatment group, means followed by different letters are significantly different based on Tukey-Kramer means separation (0.05).

${ }^{\mathrm{b}}$ Abbreviations:OSR, oilseed radish; OSR+rye, oilseed radish plus rye. 
Table 6. Profit margins (Can $\$ \mathrm{ha}^{-1}$ ) over cover crop costs for sweet corn. ${ }^{\mathrm{a}}$

\begin{tabular}{|c|c|c|c|c|c|c|}
\hline \multirow[b]{2}{*}{ Cover Crop } & \multicolumn{2}{|c|}{ Combined } & \multicolumn{2}{|c|}{ Weedy } & \multicolumn{2}{|c|}{ Nonweedy } \\
\hline & Bothwell & Ridgetown & Bothwell & Ridgetown & Bothwell & Ridgetown \\
\hline No cover & $1,630 \mathrm{~b}$ & $5,420 \mathrm{ab}$ & $1,560 \mathrm{~b}$ & $2,580 \mathrm{ab}$ & $1,700 \mathrm{a}$ & $8,260 \mathrm{a}$ \\
\hline Oat & $2,090 \mathrm{a}$ & $5,130 \mathrm{~b}$ & $2,150 \mathrm{a}$ & $2,270 \mathrm{~b}$ & $2,040 \mathrm{a}$ & $7,980 \mathrm{a}$ \\
\hline $\operatorname{OSR}^{\mathrm{b}}$ & - & $6,250 \mathrm{a}$ & - & $3,410 \mathrm{a}$ & - & $9,090 \mathrm{a}$ \\
\hline OSR+rye & $1,620 \mathrm{~b}$ & $5,970 \mathrm{ab}$ & $1,430 \mathrm{~b}$ & $3,290 \mathrm{a}$ & $1,810 \mathrm{a}$ & $8,660 \mathrm{a}$ \\
\hline Rye & $1,660 \mathrm{~b}$ & $6,220 \mathrm{a}$ & $1,550 \mathrm{~b}$ & $3,100 \mathrm{ab}$ & $1,780 \mathrm{a}$ & $9,340 \mathrm{a}$ \\
\hline
\end{tabular}

${ }^{a}$ Within a column, for a given treatment group, means followed by different letters are significantly different based on Fischer's Protected LSD (0.05).

${ }^{\mathrm{b}}$ Abbreviations: OSR, oilseed radish; OSR+rye, oilseed radish plus rye.

differences in weed density in sweet corn after wild radish and rye cover crop treatments.

The lack of consistent weed reduction during the sweet corn season may be due to preplant tillage. Cover crop residue can have a short-term or season-long weed-suppressive effect when maintained on the soil surface in no-tillage systems compared to conventional tillage systems (Ngouajio et al. 2003; Peachey et al. 2004). It would be expected that cover crops would have minimal influence on weeds in tillage-based systems compared to systems in which cover crop residues act as a mulch on the soil surface. This was observed at both sites and by other researchers (Malik et al. 2008; Ngouajio et al. 2003; Peachey et al. 2004). As well, the impact of tillage on weed density depends on the weed species present (Barberi and Mazzoncini 2001). At Bothwell and Ridgetown, the dominant weeds present were annual species, which typically dominate tillage production systems.

Although cover crops did not provide consistent weed reduction during sweet corn growth, none of the cover crop treatments resulted in higher weed populations than the nocover treatment under typical herbicide regimes, if OSR did not set viable seed. This indicates that fall cover crops may not lead to an increased need for weed management during sweet corn production. Therefore, growers should be able to adhere to their usual weed management regime when including fall cover crops in their sweet corn production system if viable OSR seeds are controlled.

Effect of Cover Crop and Weed Populations on Sweet Corn Yield. At both sites, there were no cover crop by weed treatment interactions on sweet corn total or marketable yield. There was no difference among the cover crop treatments in marketable yield at either site (Table 5). As well, at both sites, all cover crop treatments produced total yields equal to or higher than that of the no-cover control (Table 5). This general lack of effect of cover crops on sweet corn yield is consistent with other studies (Carrera et al. 2004; Galloway and Weston 1996; Malik et al. 2008) and is important for demonstrating to growers that, generally, cover crops do not lead to a decrease in main crop yield.

At Bothwell, the weedy and nonweedy treatments had no effect on marketable or total yield. This was likely due to lower weed pressure at Bothwell than at Ridgetown and weedy plots were harvested $3 \mathrm{~d}$ after the nonweedy plots, giving time for sweet corn cobs in the weedy plots to mature and perhaps increase yields. At the Ridgetown site, weedy and nonweedy plots were harvested on the same day. Here, the nonweedy treatment had higher total and marketable yields than the weedy plots, highlighting the importance of reducing weeds in sweet corn production.

At Ridgetown, there was no difference in sweet corn marketable or total yield between OSR treatments and all other treatments. This result suggests that volunteer OSR was not more competitive than other weeds in reducing sweet corn yield. The OSR treatments, as a group, had higher weed density than the cereals $(P=0.019)$, which was due to the high number of volunteer OSR. It is likely that volunteer OSR out-competed weeds, such as ragweed. Although not the objective of this study, results suggests that if volunteer OSR is controlled prior to emergence, there may be no adverse effect of OSR volunteers on sweet corn yield when weed pressure is high.

Economic Analyses. The results of the pairwise comparisons indicate that cover crop profit margins were equal to or higher than profit margins for the no-cover control at Bothwell (Table 6). In the weedy treatments, oats had a significantly higher profit margin than all other treatments, while in the nonweedy treatments there was no difference. This implies

Table 7. Parameter estimates for the effects of cover crops on profit margins broken down by weedy and weed-free plots within treatments. The model fitted was Profit Margin $\left(\right.$ Can $\left.\$ \mathrm{ha}^{-1}\right)=\mathrm{a}+\mathrm{b} \times$ Oats $+\mathrm{c} \times$ Rye $+\mathrm{d} \times$ OSR $+\mathrm{e}$ $\times(\mathrm{OSR}+\mathrm{rye}){ }^{\mathrm{a}}$

\begin{tabular}{|c|c|c|c|c|}
\hline \multirow[b]{2}{*}{ Parameter } & \multicolumn{2}{|c|}{ Weedy } & \multicolumn{2}{|c|}{ Nonweedy } \\
\hline & Estimate & SE & Estimate & SE \\
\hline \multicolumn{5}{|l|}{ Bothwell } \\
\hline $\mathrm{a}$ & $1,556^{* * *}$ & 175 & $1,697^{* * *}$ & 144 \\
\hline $\mathrm{b}$ & $590^{* *}$ & 247 & 340 & 203 \\
\hline c & -4 & 247 & 81 & 203 \\
\hline $\mathrm{d}$ & - & - & - & - \\
\hline $\mathrm{e}$ & -125 & 27 & 112 & 203 \\
\hline \multicolumn{5}{|l|}{ Ridgetown } \\
\hline $\mathrm{a}$ & $2,585^{* * *}$ & 300 & $8,259^{* * *}$ & 684 \\
\hline $\mathrm{b}$ & -311 & 424 & -275 & 968 \\
\hline c & 517 & 424 & 1,085 & 968 \\
\hline $\mathrm{d}$ & $826^{*}$ & 424 & 831 & 968 \\
\hline $\mathrm{e}$ & 702 & 424 & 404 & 968 \\
\hline
\end{tabular}

* Parameter estimates are significantly different from zero at 0.10 .

** Parameter estimates are significantly different from zero at 0.05 .

*** Parameter estimates are significantly different from zero at 0.01 . 
that when there is weed pressure, the profitability of sweet corn production is significantly higher with oats as a cover crop, as compared with other cover crop treatments at this site. At Ridgetown, when the weed treatments were combined, none of the cover crops lowered profit margins compared with no cover; however, oat had significantly lower profit margins than both the OSR and rye treatments (Table 6). There were no significant differences between any of the cover crop treatments in the nonweedy treatments, while in the weedy treatments, oat had significantly lower profit margins than the OSR and OSR+rye treatments. With the exception of the oat treatment at Bothwell, margins among all treatments at both sites were greater for the nonweedy treatments, with much greater differences observed at Ridgetown. However, it must be noted that the costs of hand-hoeing OSR plots were not accounted for.

The regression equation was a better fit for the weedy treatments with $R^{2}$ values ranging from 0.4 to 0.5 , while for the nonweedy treatments these values are around 0.2 (Table 7). At Bothwell, the parameter estimates and standard errors for the three cover crops indicate that only the oat cover crop for the weedy treatment had a statistically significant, positive effect on profit margins, increasing margins by almost Can $\$ 600 \mathrm{ha}^{-1}$ compared with the no-cover treatment (Table 7). At Ridgetown, only the OSR cover crop for the weedy treatment had a statistically significant (at the $10 \%$ level), positive impact on profit margins, relative to the nocover treatment. The parameter estimate for this treatment indicates an increase in profit margins between Can $\$ 1,253$ and Can $\$ 1,354 \mathrm{ha}^{-1}$ for OSR and between Can $\$ 682$ and Can $\$ 835 \mathrm{ha}^{-1}$ for OSR+rye. The negative parameter estimates for the oat cover crop indicates that margins for this treatment were lower than the no-cover treatment; however, this difference was not statistically significant for either the weedy or nonweedy treatments.

Overall, the results of the economic analyses imply that profitability of sweet corn production combined with the use of various cover crops may vary under different growing conditions. The oat cover crop treatment generated the highest profit margins at Bothwell, while the OSR treatment tended to generate higher profit margins than other treatments at Ridgetown. Even with higher costs than the no-cover treatment, profit margins for cover crop treatments were generally higher than those with no cover crops, although these differences were not always statistically significant. Similarly, Carrera et al. (2004) observed that cover crop increased profitability of no-till sweet corn and decreased weed pressure. Therefore, costs should not be a limiting factor for growers incorporating cover crops into their rotation, especially because the economic analyses in this study considered the cost of hiring a custom applicator to plant the cover crop and to apply the herbicide to control the rye cover crop in the spring. Creamer et al. (1996) also found that various cover cropping systems were more profitable at different locations, while Lu et al. (2000) found that the profitability of cover crops in horticultural production varied among several reviewed studies, with the majority of unprofitable cover crops being the result of decreased main crop yield, which was not observed at either site in our study.
Oats, rye, OSR, and OSR+rye cover crops are viable options to include in conventional sweet corn management systems. Results of this study indicate that in all cases cover crops prior to sweet corn production were as profitable as or more profitable than not having a cover crop. Cover crops did not lower yields compared with no cover crop and did not pose a weed problem in the following sweet corn season, provided OSR was not planted too early so as to set viable seed. Moreover, weed populations in the non-cropping season were lowered or not different than no cover crop. These positive effects were observed after $1 \mathrm{yr}$ in the rotation; one would expect the benefits of cover crops to be more evident after several years of cover crop use.

\section{Sources of Materials}

${ }^{1}$ SAS Version 9.1, SAS Institute, Cary, NC.

${ }^{2}$ Horticultural Statistics; Ontario Ministry of Agriculture, Food and Rural Affairs, 1 Stone Road West, Guelph, ON N1G 4Y2, Canada.

${ }^{3}$ AGRIS Co-operative Ltd., 835 Park Avenue West, Chatham, ON N7M 5J6, Canada.

${ }^{4}$ Provincial Survey of Custom Farmwork Charged in 2006; Ontario Ministry of Agriculture, Food and Rural Affairs, 1 Stone Road West, Guelph, ON N1G 4Y2, Canada.

\section{Acknowledgments}

Funding for this project was provided in part by Ontario Ministry of Agriculture, Food and Rural Affairs, Agriculture and Agri-Food Canada through the Agricultural Adaptation Council CORD IV program, Fresh Vegetable Growers of Ontario, as well as in-kind analyses from Agri-Food Laboratories Ltd. and A\&L Canada Laboratories Inc. Thanks are extended to Mike Zink, Elaine Roddy, and Anne Verhallen for their technical expertise.

\section{Literature Cited}

Barberi, P. and M. Mazzoncini. 2001. Changes in weed community composition as influenced by cover crop and management system in continuous corn. Weed Sci. 49:491-499.

Bollero, G. A. and D. G. Bullock. 1994. Cover cropping systems for the Central Corn Belt. J. Prod. Agric. 7:55-58.

Boydston, R. A. and A. Hang. 1995. Rapeseed (Brassica napus) green manure crop suppresses weeds in potato (Solanum tuberosum). Weed Technol. 9:669-675.

Brennan, E. B. and R. F. Smith. 2005. Winter cover crop growth and weed suppression on the central coast of California. Weed Technol. 19:1017-1024.

Burgos, N. R. and R. E. Talbert. 1996. Weed control and sweet corn (Zea mays var rugosa) response in a no-till system with cover crops. Weed Sci. 44:355-361.

Carrera, L. M., A. A. Abdul-Baki, and J. R. Teasdale. 2004. Cover crop management and weed suppression in no-tillage sweet corn production. HortScience 39:1262-1266.

Charles, K. S., M. Ngouajio, D. D. Warncke, K. L. Poff, and M. K. Hausbeck. 2006. Integration of cover crops and fertilizer rates for weed management in celery. Weed Sci. 54:326-334.

Clark, A. J., A. M. Decker, J. J. Meisinger, F. R. Mulford, and M. S. McIntosh. 1995. Hairy vetch kill date effects on soil-water and corn production. Agron. J. 87:579-585. 
Creamer, N. G., M. A. Bennett, B. R. Stinner, and J. Cardina. 1996. A comparison of four processing tomato production systems differing in cover crop and chemical inputs. J. Am. Soc. Hort. Sci. 121:559-568.

Fahey, J. W., A. T. Zalcmann, and P. Talalay. 2001. The chemical diversity and distribution of glucosinolates and isothiocyanates among plants. Phytochemistry 56:5-51.

Frye, W. W., W. G. Smith, and R. J. Williams. 1985. Economics of winter cover crops as a source of nitrogen for no-till corn. J. Soil Water Conserv 40:246-249.

Fukai, S. and B. R. Trenbath. 1993. Processes determining intercrop productivity and yields of component crops. Field Crops Res. 34:247-271.

Galloway, B. A. and L. A. Weston. 1996. Influence of cover crop and herbicide treatment on weed control and yield in no-till sweet corn (Zea mays L.) and pumpkin (Cucurbita maxima Duch.). Weed Technol. 10:341-346.

Hanson, J. C., E. Lichtenberg, A. M. Decker, and A. J. Clark. 1993. Profitability of no-tillage corn following a hairy vetch cover crop. J. Prod. Agric. 6:432-437.

Johnson, G. A., M. S. Defelice, and Z. R. Helsel. 1993. Cover crop management and weed-control in corn (Zea mays). Weed Technol. 7:425-430.

Justes, E., B. Mary, and B. Nicolardot. 1999. Comparing the effectiveness of radish cover crop, oilseed rape volunteers and oilseed rape residues incorporation for reducing nitrate leaching. Nutr. Cycling Agroecosyst. 55:207-220.

Kelly, T. C., Y. C. Lu, A. A. Abdul-Baki, and J. R. Teasdale. 1995. Economics of a hairy vetch mulch system for producing fresh-market tomatoes in the midAtlantic region. J. Am. Soc. Hort. Sci. 120:854-860.

Koger, C. H., K. N. Reddy, and D. R. Shaw. 2002. Effects of rye cover crop residue and herbicides on weed control in narrow and wide row soybean planting systems. Weed Biol. Manag. 2:216-224.

Larson, J. A., R. K. Roberts, D. D. Tyler, B. N. Duck, and S. P. Slinsky. 1998 Stochastic dominance analysis of winter cover crop and nitrogen fertilizer systems for no-tillage corn. J. Soil Water Conserv. 53:285-288.

Lichtenberg, E., J. C. Hanson, A. M. Decker, and A. J. Clark. 1994. Profitability of legume cover crops in the mid Atlantic region. J. Soil Water Conserv. 49:582-585.

Lu, Y., K. Watkins, J. R. Teasdale, and A. Abdul-Baki. 2000. Cover crops in sustainable food production. Food Rev. Int. 16:121-157.

Mailvaganam, S. 2008. Area, production and farm value of specified commercial vegetable crops, Ontario, 2007. http://www.omafra.gov.on.ca/english/stats/ hort/veg_m07.htm. Accessed: November 20, 2008.

Malik, M. S., J. K. Norsworthy, A. S. Culpepper, M. B. Riley, and W. Bridges. 2008. Use of wild radish (Raphanus raphanistrum) and rye cover crops for weed suppression in sweet corn. Weed Sci. 56:588-595.

Mallory, E. B., J. L. Posner, and J. O. Baldock. 1998. Performance, economics, and adoption of cover crops in Wisconsin cash grain rotations: on-farm trials. Am. J. Alternative Agric. 13:2-11.
Mohler, C. L. and J. R. Teasdale. 1993. Response of weed emergence to rate of Vicia villosa Roth and Secale cereale L. residue. Weed Res. 33:487-499.

Moonen, A. C. and P. Barberi. 2004. Size and composition of the weed seedbank after 7 years of different cover-crop-maize management systems. Weed Res. 44:163-177.

Ngouajio, M. and H. Mennan. 2005. Weed populations and pickling cucumber (Cucumis sativus) yield under summer and winter cover crop systems. Crop Prot. 24:521-526.

Ngouajio, M., M. E. McGiffen, Jr., and C. M. Hutchinson. 2003. Effect of cover crop and management system on weed populations in lettuce. Crop Prot. 22:57-64.

Peachey, R. E., R. D. William, and C. Mallory-Smith. 2004. Effect of no-till or conventional planting and cover crops residues on weed emergence in vegetable row crop. Weed Technol. 18:1023-1030.

Roberts, R. K., J. A. Larson, D. D. Tyler, B. N. Duck, and K. D. Dilivan. 1998. Economic analysis of the effects of winter cover crops on no-tillage corn yield response to applied nitrogen. J. Soil Water Conserv. 53:280-284.

Sarrantonio, M. and E. Gallandt. 2003. The role of cover crops in North American cropping systems. J. Crop Prod. 8:53-74.

Schomberg, H. H., D. M. Endale, A. Calegari, R. Peixoto, M. Miyazawa, and M. L. Cabrera. 2006. Influence of cover crops on potential nitrogen availability to succeeding crops in a southern piedmont soil. Biol. Fertil. Soils 42:299-307.

Simpson, E. H. 1949. Measurement of diversity. Nature 163:688.

Snapp, S. S., S. M. Swinton, R. Labarta, D. R. Mutch, J. R. Black, R. Leep, J. Nyiraneza, and K. O’Neil. 2005. Evaluating cover crops for benefits, costs and performance within cropping system niches. Agron. J. 97:322-332.

Tawaha, A. M. and M. A. Turk. 2003. Allelopathic effects of black mustard (Brassica nigra) on germination and growth of wild barley (Hordeum spontaneum). J. Agron. Crop Sci. 189:298-303.

Teasdale, J. R. 1996. Contribution of cover crops to weed management in sustainable agricultural systems. J. Prod. Agric. 9:475-479.

Turk, M. A. and A. M. Tawaha. 2003. Allelopathic effect of black mustard (Brassica nigra L.) on germination and growth of wild oat (Avena fatua L.). Crop Prot. 22:673-677.

Varco, J. J., S. R. Spurlock, and O. R. Sanabria-Garro. 1999. Profitability and nitrogen rate optimization associated with winter cover management in notillage cotton. J. Prod. Agric. 12:91-95.

Vaughn, S. F. and R. A. Boydston. 1997. Volatile allelochemicals released by Crucifer green manures. J. Chem. Ecol. 23:2107-2116.

Yiridoe, E. K., A. Weersink, R. C. Roy, and C. J. Swanton. 1993. Economic analysis of alternative cropping systems for a bean/wheat rotation on light textured soils. Can. J. Plant Sci. 73:405-415.

Received March 29, 2010, and approved March 21, 2011. 